\title{
【Short Communication】
}

\section{Osteoclast-Forming Suppressive Compounds from Anoectochilus formosanus}

\author{
Kikuko MASUDA ${ }^{1}$, Takumi KAWAGUCHI ${ }^{2}$, Tomoyuki KOYAMA ${ }^{1}$, Tomio NISHIMURA ${ }^{3}$, \\ Hirokazu KAWAGISHI ${ }^{2}$, Kazunaga YAZAWA ${ }^{1, *}$ \\ ${ }^{1}$ Laboratory of Nutraceuticals and Functional Foods Science, Graduate School of Marine Science and Technology, \\ Tokyo University of Marine Science and Technology \\ ${ }^{2}$ Graduate School of Science and Technology, Shizuoka University \\ ${ }^{3}$ Akatsuka botanical garden Co.
}

\begin{abstract}
[ABSTRACT]
Anoectochilus formosanus, an orchidaceous plant native to Taiwan, is widely used as a folk medicine in Taiwan and other Southeast Asian countries. We attempted to isolate the bioactive principles from $A$. formosanus and succeeded in purifying the compounds. Two known compounds ( $\mathrm{N}$-cis-feruloyl tyramine and $\mathrm{N}$-transferuloyl tyramine) were isolated and both significantly inhibited osteoclast formation, which is important in the development of osteoporosis.
\end{abstract}

\section{[Key words]}

Anoectochilus formosanus, osteoporosis, osteoclast-forming suppressive substance

\section{INTRODUCTION}

Osteoclasts are multinucleated cells that play a crucial role in bone resorption ${ }^{1)}$. The imbalance between bone resorption and bone formation results in osteoporosis. Therefore, substances that can suppress osteoclast formation are potential candidates for drug development or functional foods.

Anoectochilus formosanus (orchidaceae) is one of the original plants valued as a crude drug that is used as a folk medicine in Taiwan for lung disease, pleurodynia, abdominal pain, fever, hypertension, and snake bites ${ }^{2)}$. Its leaf is velutinous with very dark green color, and leaf vein is gold. That is why it is called "kinsenren" in Japanese, which literary means gold lined leaf. Shin et al. showed that the aqueous extract of $A$. formosanus produced anti-hyperglycemic and anti-oxidant effects in rats with streptozotocin-induced diabetes $^{3)}$. Shin et al. also showed that $A$. formosanus suppressed bone density loss ${ }^{4}$. We showed that $A$. formosanus inhibited osteoclast formation, apparently through the suppression of RANKL expression ${ }^{5}$.

We attempted to isolate the bioactive principles from $A$. formosanus and succeeded in purifying several compounds. These compounds were subsequently tested for their inhibitory activity on osteoclast formation.

Accepted Date: February 10, 2010

* Laboratory of Nutraceuticals and Functional Foods Science, Graduate School of Marine Science and Technology, Tokyo University of Marine Science and Technology, 4-5-7 Konan, Minato-ku, Tokyo 108-8477, Japan Tel: +81-3-5463-4053 Fax: +81-3-5463-0417 


\section{MATERIALS AND METHODS}

\subsection{General experimental procedure}

NMR spectra were measured with a Jeol Lambda-500 spectrometer. The HRESIMS data were measured by a JMST100LC mass spectrometer. A JASCO grating infrared spectrophotometer was used to record the IR spectra. HPLC separations were performed with a JASCO Gulliver system using a preparative column (Develosil C30-UG-5, Nomura Chemistry, Japan; Capcell Pak AQ 18, Shiseido Co., Ltd. Japan). Silica gel plate $\left(\right.$ Merck $\left.\mathrm{F}_{254}\right)$ and silica gel $60 \mathrm{~N}$ (Merck 100-200 mesh) were used for analytical TLC and for flash column chromatography, respectively.

\subsection{Extraction and isolation}

A. formosanus was propagated by tissue culture. In addition, $A$. formosanus used in this experiment is vegetative propagation collected from natural product, and other properties of natural products are considered to be equivalent. The dried whole parts of $A$. formosanus (500 g, 100\%) were powdered and extracted with $99.5 \%$ ethanol $(5 \mathrm{~L})$ at room temperature for 3 days. The extract was concentrated to give a red-green powder $(7.98 \%)$, which was partitioned between hexane and 90\% methanol. The 90\% methanol layer was further partitioned between $\mathrm{CH}_{2} \mathrm{Cl}_{2}$ and $60 \%$ methanol. The $\mathrm{CH}_{2} \mathrm{Cl}_{2}$ layer was fractionated by silica gel $\mathrm{CC}$ eluting with $\mathrm{CH}_{2} \mathrm{Cl}_{2}-\mathrm{Et}_{2} \mathrm{O}(10: 0-8: 2-5: 5, \mathrm{v} / \mathrm{v})$, EtOAc, and methanol to obtain 18 fractions. Fraction 4 was further separated by RPHPLC (40\% methanol) to afford compounds $1(0.005 \%)$ and 2 $(0.01 \%)$.

\subsection{Bioassay}

Osteoclast-like multinucleated cells can be differentiated in vitro from co-cultures of mouse bone marrow cells and calvarial osteoblastic cells by treatment with osteotropic factor $1 \alpha, 25$-dihydroxyvitamin $\mathrm{D}_{3}\left(1 \alpha, 25(\mathrm{OH})_{2} \mathrm{D}_{3}\right)$ prostaglandin $\mathrm{E}_{2}\left(\mathrm{PGE}_{2}\right)$. The stromal/osteoblastic cell line UAMS-32 was cultured in $\alpha$-minimal essential medium ( $\alpha$-MEM) (MP Biomedicals, Eschwege, Germany) containing 10\% fetal bovine serum (FBS) for about 1 week. The cells were then detached from the culture dishes using trypsin-EDTA, suspended in $\alpha$-MEM containing 10\% FBS and used for the co-culture as osteoblastic cells. Femoral and tibiae bone marrow cells were isolated from mice as described. The tibiae and femora were removed and dissected free of adhering tissues. The bone ends were removed and the marrow cavities flushed by slowly injecting media at one end using a 26-gauge needle. The osteoblastic and bone marrow cells collected were washed and used in the co-culture. Osteoclasts were prepared from a co-culture system as previously described ${ }^{6)}$. The osteoblastic cells $\left(1.0 \times 10^{4}\right.$ cells/well $)$ were co-cultured with bone marrow cells $\left(2.0 \times 10^{7}\right.$ cells/well $)$ in $\alpha$-MEM containing $10 \%$ FBS in 96-well plates (Corning, NY, USA). The culture volume was made up to $200 \mu \mathrm{l}$ per well with $\alpha$-MEM supplemented with $10 \% \mathrm{FBS}$, in the presence of $10^{-8} \mathrm{M} 1 \alpha$, $25(\mathrm{OH})_{2} \mathrm{D}_{3}$ (Biomol, Plymouth Meeting, PA, USA) and $10^{-6} \mathrm{M}$ $\mathrm{PGE}_{2}$, with or without sample. Samples were dissolved in methanol. All cultures were maintained at $37^{\circ} \mathrm{C}$ in a humidified atmosphere containing $5 \% \mathrm{CO}_{2}$. After co-culture for 3 days, three-quarters of the medium was changed and supplemented with $1 \alpha, 25(\mathrm{OH})_{2} \mathrm{D}_{3}$ and $\mathrm{PGE}_{2}$ with or without sample.

After cultivation, the adherent cells were fixed with $10 \%$ formaldehyde in $10 \mathrm{mM}$ phosphate-buffered saline $(\mathrm{pH}=7.4)$ for $20 \mathrm{~min}$. After treatment with $95 \%$ ethanol for $1 \mathrm{~min}$, the well surface was dried and treated with TRAP staining solution $[0.1 \mathrm{M}$ sodium acetate buffer $(\mathrm{pH} 5.0)$ containing $50 \mathrm{mM}$ sodium tartrate, $0.1 \mathrm{mg} / \mathrm{ml}$ naphthol AS-MX phosphate (Sigma Chemical, St. Louis, MO, USA), and $1 \mathrm{mg} / \mathrm{ml}$ fast red violet LB salt (Sigma Chemical)] for $30 \mathrm{~min}$. Then, TRAP-positive multinucleated cells were counted under a microscope.

Cell viability was evaluated using a 3-[4,5-dimethylthiazol2-yl]-2,5-diphenyl tetrazolium bromide (MTT) (Sigma Chemical) assay. After culture, cells were treated with $1 \mathrm{mg} / \mathrm{ml}$ MTT for $2 \mathrm{~h}$, then precipitated dye was solubilized into dimethylsulfoxide and the absorbance $(570 \mathrm{~nm})$ was measured

\subsection{Statistical analysis}

Data were statistically analyzed using Student's $t$-test to determine significant differences in the data among the groups. $p$ values $<0.05$ were considered significant. The values are expressed as mean \pm S.E.

\section{RESULTS AND DISCUSSION}

Compounds 1 and 2 were isolated as viscous oils. The molecular formulas for both compounds were determined to be $\mathrm{C}_{18} \mathrm{H}_{19} \mathrm{NaNO}_{4}$ by HR-ESIMS analysis data $[\mathrm{m} / \mathrm{z} 336.12018$ and $336.12102[\mathrm{M}+\mathrm{Na}]^{+}$(calcd. for $\mathrm{C}_{18} \mathrm{H}_{19} \mathrm{NaNO}_{4}$, 336.11872)], indicating the presence of 10 degrees of unsaturation in the molecules. The ${ }^{1} \mathrm{H}$ - and ${ }^{13} \mathrm{C}-\mathrm{NMR}$ data showed that these compounds were $\mathrm{N}$-cis-feruloyl tyramine and $\mathrm{N}$-trans-feruloyl tyramine, respectively (Fig. 1). These 


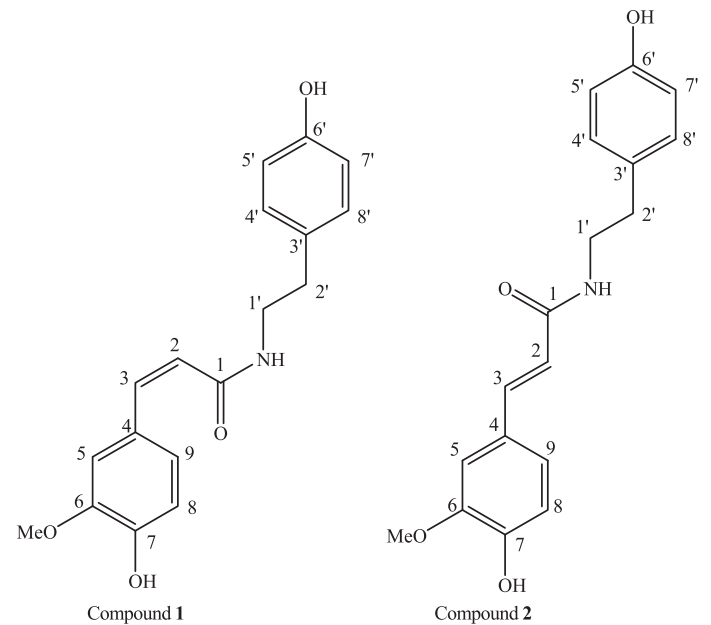

Fig. 1 Structure of compounds 1 and 2

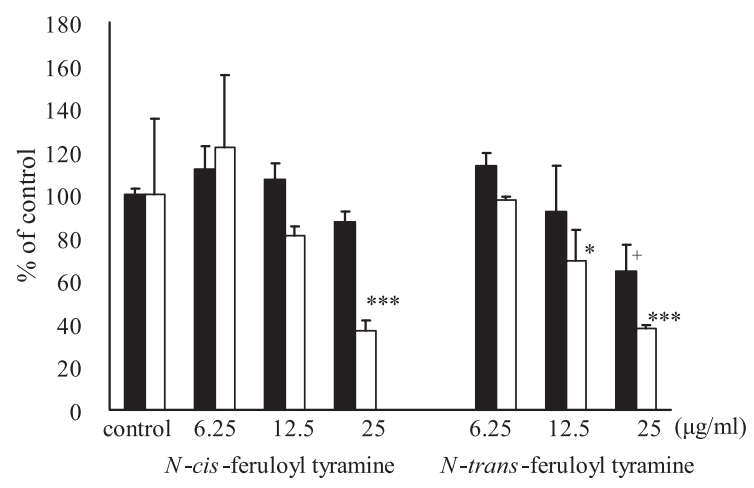

Fig. 2 Inhibition of osteoclast formation by compounds 1 and 2 Closed and open columns indicate cell viability and osteoclast formation, respectively. TRAP-positive multinucleated cells that had more than three nuclei were counted. Cell viability was determined by MTT assay. Data are the mean \pm S.E of four cultures. ${ }^{*} p<0.05$ and ${ }^{* * *} p<0.005 v s$. Control using Student's $t$-test (TRAP). ${ }^{+} p<0.05 v s$. Control using Student's $t$-test (MTT).

compounds have been isolated from the fruits of white pepper and their antioxidant activities have been reported ${ }^{7}$. Osteoclast differentiation was estimated by TRAP-(+) multinucleated cell formation in osteoblastic/bone marrow cells co-culture. The number of differentiated osteoclasts induced by $1 \alpha$, $25(\mathrm{OH})_{2} \mathrm{D}_{3}$ and $\mathrm{PGE}_{2}$ was $500 \pm 254.37 \mathrm{cells} / \mathrm{cm}^{2}$. The addition of 1 and 2 reduced the number of TRAP- $(+)$ multinucleated cells to $36 \%$ at $25 \mu \mathrm{g} / \mathrm{ml}$ and $68 \%$ at $12.5 \mu \mathrm{g} / \mathrm{ml}$ without cytotoxicity, respectively (Fig. 2). Therefore, we presume that it would be difficult to prove all the activities of extract as to these strength of activity.

\section{CONCLUSION}

This is the first report of the isolation of $\mathrm{N}$-cis- and $\mathrm{N}$-transferuloyl tyramine from Anoectochilus formosanus. These compounds significantly inhibited osteoclast formation, which is important in the development of osteoporosis.

Compound 1. $\mathrm{N}$-cis-feruloyl tyramine, ${ }^{1} \mathrm{H}-\mathrm{NMR} \delta_{\mathrm{H}}\left(\mathrm{CDCl}_{3}\right)$ $5.80(1 \mathrm{H}, \mathrm{d}, J=12.6 \mathrm{~Hz}, \mathrm{H}-2), 6.60(1 \mathrm{H}, \mathrm{d}, J=12.6 \mathrm{~Hz}, \mathrm{H}-3)$, $7.34(1 \mathrm{H}, \mathrm{d}, J=1.1 \mathrm{~Hz}, \mathrm{H}-5), 6.78$ (1H, d, $J=8.1 \mathrm{~Hz}, \mathrm{H}-8), 6.91$ (1H, dd, $J=8.1 \mathrm{~Hz}, 1.3, \mathrm{H}-9), 3.82$ (3H, s, 6-OMe), 3.39 (2H, t, $\left.J=7.5 \mathrm{~Hz}, \mathrm{H}-1^{\prime}\right), 2.68$ (2H, t, $J=7.5 \mathrm{~Hz}, \mathrm{H}-2^{\prime}$ ), 6.99 (2H's, d, $J$ $=8.2 \mathrm{~Hz}, \mathrm{H}-4$ ', 8'), 6.68 (2H's, d, $J=8.2 \mathrm{~Hz}, \mathrm{H}-5$ ', 7'); ${ }^{13} \mathrm{C}-\mathrm{NMR}$ $\delta_{\mathrm{c}}\left(\mathrm{CDCl}_{3}\right) 170.3(\mathrm{C}-1), 121.7(\mathrm{C}-2), 138.3(\mathrm{C}-3), 128.6(\mathrm{C}-4)$, 114.0 (C-5), 148.5 (C-6), 148.6 (C-7), 115.8 (C-8), 124.8 (C9), 56.4 (6-OMe), 42.3 (C-1'), 35.6 (C-2'), 131.2 (C-3'), 130.7 (C-4', 8'), 116.3 (C-5', 7'), 156.9 (C-6').

Compound 2. N-trans-feruloyl tyramine, ${ }^{1} \mathrm{H}-\mathrm{NMR} \delta_{\mathrm{H}}$ $\left(\mathrm{CDCl}_{3}\right) 6.39(1 \mathrm{H}, \mathrm{d}, J=15.6 \mathrm{~Hz}, \mathrm{H}-2), 7.43(1 \mathrm{H}, \mathrm{d}, J=15.6 \mathrm{~Hz}$, H-3), 7.08 (1H, d, J=1.1 Hz, H-5), $6.78(1 \mathrm{H}, \mathrm{d}, J=8.2 \mathrm{~Hz}, \mathrm{H}-$ 8), 7.00 (1H, dd, $J=8.1 \mathrm{~Hz}, 1.3, \mathrm{H}-9), 3.85$ (3H, s, 6-OMe), 3.45 (2H, t, $\left.J=7.3 \mathrm{~Hz}, \mathrm{H}-1^{\prime}\right), 2.73$ (2H, t, $\left.J=7.3 \mathrm{~Hz}, \mathrm{H}-2^{\prime}\right), 7.03$ (2H's, d, J=8.5 Hz, H-4', 8'), 6.71 (2H's, d, $J=8.5 \mathrm{~Hz}, \mathrm{H}-5$ ', 7'); ${ }^{13} \mathrm{C}-\mathrm{NMR} \delta_{\mathrm{c}}\left(\mathrm{CDCl}_{3}\right) 169.1(\mathrm{C}-1), 118.8(\mathrm{C}-2), 142.0(\mathrm{C}-3)$, 128.3 (C-4), 111.5 (C-5), 149.2 (C-6), 149.8 (C-7), 116.5 (C8), 123.2 (C-9), 56.4 (6-OMe), 42.5 (C-1'), 36.8 (C-2'), 131.3 (C-3'), 130.7 (C-4', 8'), 116.3 (C-5', 7'), 156.8 (C-6').

\section{REFERENCES}

1) Baron R. Molecular mechanisms of bone resorption by the osteoclast. Anat Rec 1989; 224(2): 317-324.

2) Lin CC, Huang PC, Lin JM. Antioxidant and hepatoprotective effects of Anoectochilus formosanus and Gynostema pentaphyllum. Am J Chin Med 2000; 28(1): 87-96.

3) Shih CC, Wu YW, Lin WJ. Antihyperblycemic and anti-oxidant properties of Anoectochilus formosanus in diabetic rats. Clin and Exper Pharmacol and physiol 2002; 29(8): 684-688.

4) Shih CC, Wu YW, Lin WC. Ameliorative effects of Anoectochilus formosanus extract on osteopenia in ovariectomized rats. $\mathrm{J}$ Ethnopharmacol 2001; 77(2-3): 233-238.

5) Masuda K, Ikeuchi M, Koyama T, et al. Suppressive effects of Anoectochilus formosanus extract on osteoclast formation in vitro and bone resorption in vivo. J Bone Miner Metab 2008; 26(2): 123-129.

6) Takami M, Woo JT, Nagai K. Osteoblastic cells induce fusion and activation of osteoclasts through a mechanism independent of macrophage-colony-stimulating factor production. Cell Tissue 
Res 1999; 298(2): 327-334.

7) Fukuda N, Yonemitsu M, Kimura T. N-trans- and N-cis-Feruloyl
Tyramine, and a New Phenolic Glucoside, Tinotuberide. Chem Pharm Bull 1983; 31(1): 156-161.

\author{
要 旨 \\ 金線蓮抽出物による破骨細胞形成抑制成分の解析

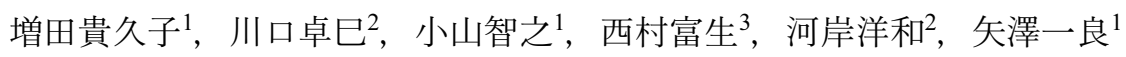 \\ 1東京海洋大学大学院海洋科学技術研究科ヘルスフード科学 (中島董一郎記念) 寄附講座 \\ 2静岡大学大学院農学研究科応用生物化学専攻 \\ 3株式会社赤塚植物園
}

金線蓮 (Anoectochilus formosanus) は, 南西諸島南部と台湾に自生しているラン科の多年性植物である. 卵巣摘出ラッ トでの骨密度減少抑制効果の報告はあるが，その活性成分本体は解明されていない，そこで各種クロマトグラフィ一等 を用い，金線蓮抽出物から2つの破骨細胞形成抑制物質を単離した.

キーワード：金線蓮，骨粗鬆症，破骨細胞形成抑制物質 